\title{
Effects of Cultural Practices and Temperature on Fusarium Root and Crown Rot of Container-Grown Hostas
}

\author{
B. Wang and S. N. Jeffers, Department of Plant Pathology and Physiology, Clemson University, Clemson, SC \\ 29634-0377
}

\section{ABSTRACT}

Wang, B., and Jeffers, S. N. 2002. Effects of cultural practices and temperature on Fusarium root and crown rot of container-grown hostas. Plant Dis. 86:225-231.

Fusarium root and crown rot of hosta plants grown in containers is caused primarily by Fusarium hostae. In an effort to develop an integrated strategy for managing this disease at nurseries, the effects of wounding, container mix content, watering schedule, and temperature on disease development were investigated. Plants were not wounded or were wounded by severing the roots, severing the roots and making incisions in the crown, or severing the roots and removing a small piece of the crown. Plants were inoculated by dipping roots and crowns into a suspension of conidia from one of two isolates of $F$. hostae. In addition, some plants were inoculated by wounding crowns with a scalpel dipped in a conidium suspension. Disease development was examined on plants grown at different temperatures $\left(18,25\right.$, or $\left.32^{\circ} \mathrm{C}\right)$, grown in different container mixes (100\% Canadian sphagnum peat, $100 \%$ aged and processed pine bark, or a mixture of $50 \%$ peat and $50 \%$ bark), and watered on different schedules (which kept the container mix wet, moist, or dry). Significant levels of disease occurred only on plants that were wounded when inoculated. Fusarium root and crown rot was more severe when both the roots and crowns were wounded than when only the roots were wounded. Disease symptoms developed when crowns of plants were wounded with a scalpel infested with conidia, suggesting that contaminated tools used for vegetative propagation may transfer F. hostae. Disease development also was affected significantly by container mix content, watering schedule, and temperature. In separate experiments, disease was most severe on plants grown in $100 \%$ aged pine bark, in dry container mix, or at 18 to $25^{\circ} \mathrm{C}$. Disease development was significantly less when plants were grown in $100 \%$ peat, in wet container mix, or at $32^{\circ} \mathrm{C}$. These results suggest that altering or manipulating cultural practices used to produce hostas in containers at nurseries can reduce the impact from Fusarium root and crown rot.

Hostas (Hosta spp.) are one of the most popular herbaceous perennial plants grown in landscapes in the United States because they have attractive foliage, thrive in shady environments, and are adapted to diverse geographical locations $(2,25)$. Consequently, hostas are one of the more common container-grown plants produced in ornamental crop nurseries. Fusarium root and crown rot is a disease that was recently described on hosta plants (36). It is caused primarily by Fusarium hostae, a newly identified species (11), but also can be

Corresponding author: S. N. Jeffers

E-mail: sjffrs@clemson.edu

Current address of B. Wang: CSIRO Plant Industry, GPO Box 1600, Black Mountain, ACT 2601, Australia.

This research was supported in part by a grant (SC001749) from the Clemson University Program for Enhancement of Research and Extension in Ornamental Horticulture.

Technical Contribution No. 4635 of the South Carolina Agriculture and Forestry Research System, Clemson University.

Accepted for publication 14 October 2001.

Publication no. D-2002-0102-02R

(C) 2002 The American Phytopathological Society caused by $F$. solani and F. oxysporum (36). This disease first was observed in 1997 on container-grown hostas at a large production nursery in South Carolina (36). Symptoms include chlorosis, stunting, vascular discoloration in roots, and necrosis of crowns. By 1999, the disease had been identified at four other nurseries in South Carolina (36), and it may occur in nurseries in other states where large quantities of hostas are produced in containers. Recently, Baayen et al. (3) used DNA amplification and sequencing to demonstrate that isolates previously identified as $F$. $o x$ ysporum f. sp. hyacinthi actually belong to $F$. hostae. Therefore, F. hostae also causes root and bulb rot on hyacinths (Hyacinthus spp.) and may be widespread on hyacinths in the Netherlands (3).

Strategies for managing Fusarium root and crown rot on container-grown hostas have not been developed. Crop rotation (33) and preplant soil fumigation $(18,20)$ are management strategies that have reduced the severity of similar Fusarium diseases on field-grown crops, but these options would not be useful for managing disease on container-grown hostas. One of the many reasons hostas and other ornamental crops are grown in soilless mixes in new or decontaminated pots is to avoid resident inocula of soilborne pathogens. In addition, infested soil does not appear to be an important source of primary inoculum for this disease (36). Use of host resistance has been an effective means of managing Fusarium diseases on other crops (6) and may be an effective option for managing disease on hostas because of the number of available species and cultivars (25). However, identification and selection of resistant genotypes will take time and may be confounded by the uncertain taxonomy in the genus Hosta (25). Some fungicides and biological control products have effectively limited Fusarium diseases on other crops $(8,18)$, but few products are labeled for diseases caused by Fusarium spp. on ornamental crops $(13,16)$.

In previous studies, it was demonstrated that Fusarium root and/or crown rots were affected significantly by cultural practices and environmental conditions. For example, more disease occurred on asparagus plants wounded by cultivation than on nonwounded plants (24), on tomato plants grown in peat or compost than on those grown in rockwool (12), on cucumber plants grown at $17^{\circ} \mathrm{C}$ compared with $29^{\circ} \mathrm{C}$ (32), and on bean plants grown under dry conditions compared with wet conditions (21).

In nurseries, hostas periodically are transplanted into larger containers, which can damage roots, and often are propagated vegetatively by dividing crowns. Previously, we have suggested that wounding may be necessary for infection and that primary infection may occur during the division process (36). Therefore, the first objective of this study was to determine the effect of different types of wounds on development of Fusarium root and crown rot. The second objective was to investigate the effects of container mix content, watering schedule, and temperature on disease development. Our overall goal was to identify cultural practices that limit the development and spread of this disease in wholesale production nurseries. Preliminary results have been reported (35).

\section{MATERIALS AND METHODS}

Hosta plants. All experiments were conducted with tissue-culture-propagated plants of $H$. 'Francee' (Agri-Starts III, Inc., Eustis, FL), each of which initially had four to six leaves. Plants were received in 72-cell propagation trays, transplanted into fresh container mix (Nursery Mix: 75\% bark and 25\% peat; Fafard, Inc., Anderson, $\mathrm{SC}$ ) in $10 \times 10-\mathrm{cm}$ square plastic pots, and 
were grown for at least 2 weeks in the greenhouse $\left(15\right.$ to $\left.30^{\circ} \mathrm{C}\right)$ before use. Plants in all experiments were fertilized once a week with a dilute solution of watersoluble fertilizer (Peters Professional 2010-20 Peat-Lite Special, The Scotts Co., Marysville, $\mathrm{OH}$ ).

Inoculum preparation. The two isolates of $F$. hostae used in this study, F12 and F46, were isolated from symptomatic 'Fortunei Albomarginata' and 'Gold Standard' hosta plants, respectively, from a nursery in South Carolina. Each isolate was subcultured from a single conidium and stored on 0.25 -strength potato dextrose agar (Difco Laboratories, Detroit, MI) in an 8-ml, screw-cap glass vial at $4^{\circ} \mathrm{C}$ in the dark. Pathogenicity had been determined previously, and disease severity was greater with isolate F12 than with isolate F46 (36). In each experiment, six to eight replicate plants were inoculated independently with each isolate, and an equal number of noninoculated plants were used as controls.

Inocula of $F$. hostae were prepared from broth cultures. Isolates were transferred from stock cultures into $125 \mathrm{ml}$ of potato dextrose broth (Difco Laboratories) in 250$\mathrm{ml}$ Erlenmeyer flasks. Flasks were placed on an orbital shaker (150 rpm), and cultures were incubated at room temperature ( 21 to $24^{\circ} \mathrm{C}$ ) for 1 week. Culture suspensions then were poured through four layers of cheesecloth to separate conidia from fragments of hyphae. Conidium suspensions, which contained mostly microconidia, were enumerated using a hemacytometer, standardized to $1 \times 10^{6} \mathrm{conidia} / \mathrm{ml}$ by diluting culture filtrates with sterile distilled water (36), and adjusted to a $\mathrm{pH}$ of 5.0 with $0.05 \mathrm{~N} \mathrm{HCl} \mathrm{(34).}$

Effects of different types of wounds on disease development. Three types of wounds and two inoculation methods were evaluated. Plants were gently removed from pots, and container mix debris was carefully removed to minimize damage to the roots and crowns prior to wounding and inoculation. Six treatments were compared: (i) all roots were severed with scissors $5 \mathrm{~cm}$ from the rhizome, crowns were scored with a scalpel by making two perpendicular incisions $(5 \mathrm{~mm}$ long and $2 \mathrm{~mm}$ deep) at the base of the crown, and roots and crowns were dipped in distilled water (noninoculated control); (ii) roots and crowns were not wounded and were dipped in a conidium suspension for $5 \mathrm{~min}$; (iii) roots were severed and roots and crowns were inoculated by dipping; (iv) roots were severed, crowns were scored, and roots and crowns were inoculated by dipping; (v) roots were severed, crowns were sliced with a scalpel by removing a small piece $\left(2 \mathrm{~mm}^{2}, 1\right.$ $\mathrm{mm}$ deep) from the side of the crown, and roots and crowns were inoculated by dipping; and (vi) roots were severed and crowns were scored with a scalpel that had been dipped into a conidium suspension.
The number of replicate plants used among treatments and between trials varied somewhat because of plant availability and space limitations in the growth room. Eight replicate plants were used in the first trial and seven replicate plants were used in the second trial for all treatments except the infested scalpel treatment, in which six replicate plants were used in each trial. All plants were transplanted into fresh Nursery Mix in $10 \times 10-\mathrm{cm}$ square plastic pots and then placed in a walk-in growth room at 20 to $22^{\circ} \mathrm{C}$ with a $14-\mathrm{h}$ photoperiod and a light intensity of $50 \mu \mathrm{E} \cdot \mathrm{s}^{-1} \cdot \mathrm{m}^{-2}$. The experiment was conducted twice.

Effects of container mix on disease development. Hosta plants were grown in three container mixes that varied in relative volumes of Canadian sphagnum peat and aged and processed pine bark (both from Fafard, Inc.). Treatment mixes contained $100 \%$ peat, $100 \%$ bark, and a mixture of $50 \%$ peat and $50 \%$ bark. The nursery-grade peat was a light-colored or blonde peat from the upper horizons of the soil profile. The pine bark had been aged for 8 to 12 months and turned periodically, but it had not been composted. After aging, it was screened and blended so that it contained a mixture of $16-\mathrm{mm}, 10-\mathrm{mm}$, and smallersized pieces. The $\mathrm{pHs}$ of the bark, the peatbark mixture, and the peat were 3.8, 3.6, and 3.4 , respectively, as determined by the saturation extraction method (37).

Plants were removed from pots, and container mix debris was gently removed from the roots and crowns. On each plant, roots were severed and the crown was scored as described previously. Plants were inoculated by dipping wounded roots and crowns for $5 \mathrm{~min}$ into a conidium suspension of either isolate F12 or isolate F46. Additional plants were dipped in distilled water and served as controls. Each plant was transplanted into one of the treatment mixes in a $10 \times 10-\mathrm{cm}$ square plastic pot. Inoculated and control plants were grown in a growth room with environmental conditions as stated above. Seven replicate plants were used for each treatment, and the experiment was conducted twice.

Effects of watering schedule on disease development. Hosta plants were inoculated as described above for the container mix experiment, transplanted into fresh Nursery Mix, and grown in a greenhouse with supplemental fluorescent lights at 15 to $30^{\circ} \mathrm{C}$ under three distinct watering schedules, which kept the container mix in pots wet, moist, or dry. For the wet treatment, $10-\mathrm{cm}$ square pots were placed in saucers $15 \mathrm{~cm}$ in diameter and $2 \mathrm{~cm}$ deep and plants were watered daily; container mix in this treatment remained partially saturated. In the moist treatment, plants were watered once every 3 days; the container mix never became visibly dry. For the dry treatment, plants were watered once a week; the container mix in these pots was visibly dry for several days be- tween water applications. Seven replicate plants were used for each treatment, and the experiment was conducted twice.

Effects of temperature on disease development. Hosta plants were inoculated as described above for the container mix experiment, were transplanted into fresh Nursery Mix, and then were grown at three temperatures $\left(18,25\right.$, and $\left.32^{\circ} \mathrm{C}, \pm 1^{\circ} \mathrm{C}\right)$ in separate growth rooms. Photoperiods (14 h) and light intensities $\left(50 \mu \mathrm{E} \cdot \mathrm{s}^{-1} \cdot \mathrm{m}^{-2}\right)$ were uniform in all three rooms. Plants grown at higher temperatures were watered more frequently than those grown at lower temperatures so the relative moisture content of the container mixes in pots in all three growth rooms remained similar throughout the experiment. The relative moisture content of each pot was monitored daily by visual appearance of the container mix surface and by lifting to determine approximate weight. Seven replicate plants were used for each treatment, and the experiment was conducted twice.

Disease assessment. In all experiments, the plants were evaluated for disease development 5 weeks after inoculation. Each plant was removed from the pot, the roots and crown were washed carefully under running tap water to remove container mix debris, and the plant was blotted with paper towels and air-dried at room temperature $\left(20\right.$ to $\left.25^{\circ} \mathrm{C}\right)$ for $30 \mathrm{~min}$ to remove excess moisture. Fresh weights of individual plants were measured in all experiments. For the container mix, watering schedule, and temperature experiments, reduction in plant growth was calculated by subtracting the weight of each inoculated plant from the mean weight of plants in the noninoculated control treatment. Disease severity was assessed by splitting the plants longitudinally through the crown with a scalpel and rating symptom development in the roots and crown on a scale of 0 to 5 , where $0=$ no discoloration, $1=$ slight discoloration of vascular tissue in roots, 2 = extensive discoloration of vascular tissue in roots, 3 = slight discoloration of vascular tissue and cortex in the crown, $4=$ extensive discoloration of vascular tissue and cortex in the crown, and $5=$ crown completely necrotic (36). Disease incidence was assessed as the proportion of plants in a treatment with symptoms of Fusarium root and crown rot.

Experimental design and statistical analysis. Data were analyzed using MINITAB for Windows, Release 12.2, (Minitab Inc., State College, PA) and The SAS System for Windows, Release 8, (The SAS Institute, Inc., Cary, NC), using the general linear model, two-way analysis of variance (ANOVA), and one-way ANOVA options for disease severity, plant weight, and plant growth reduction data. The chi-square option was used for disease incidence data because it was binomial. Data from repeated trials of individual experiments were combined for analysis when vari- 
ances between trials were homogeneous and there was no significant effect $(P>$ $0.05)$ of trial or no significant $(P>0.05)$ interaction between trial and other treatment factors.

In all experiments, treatments were arranged in a completely randomized design. Experiments were designed as two-way factorials to examine the interaction between inoculum treatments (noninoculated control, isolate F12, and isolate F46) and a cultural practice (type of wound, container mix content, and watering schedule) or temperature. For disease severity, only data for treatments with isolates F12 and F46 of $F$. hostae were analyzed because no disease symptoms occurred on noninoculated control plants regardless of the cultural practice or temperature involved. For plant weight data, all three inoculum treatments were used in data analyses because control plants were affected by the cultural practice and temperature treatments. Analyses of plant growth reduction data had only the two isolate treatments (F12 and F46) because weights of control plants were used to calculate growth reductions caused by $F$. hostae. When interactions in two-way ANOVAs were not significant $(P>0.05)$, main effects of cultural practices or temperature were compared. If interactions in

Table 1. $P>F$ values from two-way analyses of variance for four factorial experiments on the effects of wounding, container mix, watering schedule, and temperature on root and crown rot of Hosta 'Francee' plants inoculated with two isolates of Fusarium hostae ${ }^{\mathrm{x}}$

\begin{tabular}{|c|c|c|c|c|}
\hline \multirow[b]{2}{*}{ Experiment } & \multirow{2}{*}{$\begin{array}{l}\text { ANOVA } \\
\text { factor }^{\mathrm{y}}\end{array}$} & \multicolumn{3}{|c|}{ Disease parameter $^{\mathbf{z}}$} \\
\hline & & Disease severity & Plant weight & Plant growth reduction \\
\hline Wounding & $\begin{array}{l}\text { Isolate } \\
\text { Wound type } \\
\text { Interaction }\end{array}$ & $\begin{array}{c}0.003^{*} \\
<0.001^{*} \\
0.060\end{array}$ & $\begin{array}{c}<0.001^{*} \\
<0.001^{*} \\
0.118\end{array}$ & $\begin{array}{l}\ldots \\
\cdots \\
\ldots\end{array}$ \\
\hline Container mix & $\begin{array}{l}\text { Inoculum } \\
\text { Isolate } \\
\text { Container mix } \\
\text { Interaction }\end{array}$ & $\begin{array}{c}\ldots \\
0.243 \\
<0.001 * \\
0.950\end{array}$ & $\begin{array}{c}<0.001^{*} \\
\ldots \\
<0.001 * \\
0.066\end{array}$ & $\begin{array}{c}\ldots \\
0.201 \\
<0.001 * \\
0.373\end{array}$ \\
\hline Watering schedule & $\begin{array}{l}\text { Inoculum } \\
\text { Isolate } \\
\text { Watering } \\
\text { Interaction }\end{array}$ & $\begin{array}{c}\ldots \\
0.055 \\
<0.001 * \\
0.143\end{array}$ & $\begin{array}{l}0.004 * \\
\ldots \\
0.250 \\
0.614\end{array}$ & $\begin{array}{l}\ldots \\
0.046^{*} \\
0.055 \\
0.804\end{array}$ \\
\hline Temperature & $\begin{array}{l}\text { Inoculum } \\
\text { Isolate } \\
\text { Temperature } \\
\text { Interaction }\end{array}$ & $\begin{array}{c}\ldots .036^{*} \\
<0.001^{*} \\
0.147\end{array}$ & $\begin{array}{c}<0.001^{*} \\
\ldots \\
<0.001^{*} \\
<0.001^{*}\end{array}$ & $\begin{array}{c}\ldots .338 \\
<0.001^{*} \\
0.551\end{array}$ \\
\hline
\end{tabular}

${ }^{\mathrm{x}}$ Results are for two trials of each experiment with 6 to 8 replicate plants per treatment in each trial.

${ }^{y}$ For each experiment, an independent analysis of variance (ANOVA) was conducted for each disease parameter. ANOVAs for disease severity and plant weight had main effects for isolates and a cultural practice or temperature. ANOVAs for plant growth reduction had main effects for inoculum (two isolates and an non-inoculated control) and a cultural practice or temperature; plant growth reduction was not measured in the wounding experiment.

${ }^{z} P$ values were significant if $P \leq 0.05\left(^{*}\right)$ and are blank (...) if an ANOVA factor was not relevant to a particular analysis.

two-way ANOVAs were significant $(P \leq$ $0.05)$, the effect of the cultural practice or temperature on each inoculum treatment was determined independently by oneway ANOVAs. Treatments means were separated using the Tukey-Kramer test for unbalanced data or Fisher's protected least significant difference (LSD) for balanced data, with $P=0.05$ in all cases.

\section{RESULTS}

Variances between trials were homogeneous in all cases. The effect of trial and the interaction between trial and treatment factors were significant in only one ANOVA. Both the main effect of trial and the trial interaction were significant $(P<$ 0.001 and $P=0.022$, respectively) in the analysis of the effect of temperature on plant growth reduction. However, these effects were caused by differences in magnitude and not by differences in rank among individual treatments in the two trials. The ranking of treatments was the same in trial 1 , trial 2 , and in the combination of trials 1 and 2. Therefore, results for all experiments are presented based on combined trials.

Isolates F12 and F46 of $F$. hostae caused root and crown rot on $H$. 'Francee' plants in all experiments (Tables 1 to 3 ), and noninoculated control plants never developed symptoms (Tables 2 and 3). For disease severity and plant growth reduction data, interactions between isolate treatments (F12, F46) and cultural practice or temperature treatments were not significant in all experiments (Table 1). For plant weight data, interactions between inoculum treatments (isolates and controls) and cultural practice or temperature treatments were not significant in three of the experiments, but the interaction was significant in the temperature experiment (Table 1). This interaction was caused by differential

Table 2. Incidence of disease symptoms on Hosta 'Francee' plants inoculated with two isolates of Fusarium hostae (F12 and F46) or not inoculated (Control) in experiments on the effects of container mix, watering schedule, and temperature on root and crown rot ${ }^{4}$

\begin{tabular}{|c|c|c|c|c|c|c|c|c|c|}
\hline \multirow[b]{2}{*}{ Experiment } & \multirow[b]{2}{*}{ Treatment } & \multicolumn{2}{|c|}{ Isolate F12 } & \multicolumn{2}{|c|}{ Isolate F46 } & \multicolumn{2}{|c|}{ Combined $^{v}$} & \multicolumn{2}{|c|}{ Control } \\
\hline & & No. & Percent & No. & Percent & No. & Percent & No. & Percent \\
\hline \multirow[t]{4}{*}{ Container $\operatorname{mix}^{\mathrm{w}}$} & $100 \%$ bark & $14 / 14$ & 100 & $14 / 14$ & 100 & $28 / 28$ & 100 & $0 / 14$ & 0 \\
\hline & $\begin{array}{l}50 \% \text { bark }+ \\
50 \% \text { peat }\end{array}$ & $14 / 14$ & 100 & $12 / 14$ & 86 & $26 / 28$ & 93 & $0 / 14$ & 0 \\
\hline & $100 \%$ peat & $11 / 14$ & 79 & $12 / 14$ & 86 & $23 / 28$ & 82 & $0 / 14$ & 0 \\
\hline & $P>\chi^{2 \mathrm{z}}$ & 0.040 & & 0.331 & & 0.052 & & 1.000 & \\
\hline \multirow[t]{4}{*}{ Watering schedule ${ }^{\mathrm{x}}$} & Dry & $14 / 14$ & 100 & $14 / 14$ & 100 & $28 / 28$ & 100 & $0 / 14$ & 0 \\
\hline & Moist & $14 / 14$ & 100 & $14 / 14$ & 100 & $28 / 28$ & 100 & $0 / 14$ & 0 \\
\hline & Wet & $8 / 14$ & 57 & $9 / 14$ & 64 & $17 / 28$ & 61 & $0 / 14$ & 0 \\
\hline & $P>\chi^{2 z}$ & 0.001 & & 0.003 & & 0.001 & & 1.000 & \\
\hline \multirow[t]{4}{*}{ Temperature $^{\mathrm{y}}$} & $18^{\circ} \mathrm{C}$ & $14 / 14$ & 100 & $14 / 14$ & 100 & $28 / 28$ & 100 & $0 / 14$ & 0 \\
\hline & $25^{\circ} \mathrm{C}$ & $14 / 14$ & 100 & $14 / 14$ & 100 & $28 / 28$ & 100 & $0 / 14$ & 0 \\
\hline & $32^{\circ} \mathrm{C}$ & $14 / 14$ & 100 & $13 / 14$ & 93 & $27 / 28$ & 96 & $0 / 14$ & 0 \\
\hline & $P>\chi^{2 \mathrm{z}}$ & 1.000 & & 0.359 & & 0.364 & & 1.000 & \\
\hline
\end{tabular}

$\overline{\mathrm{u}}$ Two trials were conducted for each experiment, and seven replicate plants were used for each treatment in each trial.

${ }^{v}$ Disease incidence when results for the two isolates were combined.

${ }^{\mathrm{w}}$ Inoculated plants were grown in container mixes composed of different percentages of aged pine bark and sphagnum peat.

${ }^{x}$ Inoculated plants were watered on different schedules so that the container mix in pots in each treatment had a different relative moisture content.

${ }^{y}$ Inoculated plants were grown in growth rooms at different temperatures.

${ }^{\mathrm{z}}$ Probability of a greater $\chi^{2}$ value in a $3 \times 2$ contingency table with 2 degrees of freedom. 
effects on inoculated and noninoculated plants and not by differential effects between isolates. The overall lack of significant interactions in analyses indicates that the two isolates of $F$. hostae affected plants similarly in these experiments. Consequently, except for plant weight in the temperature experiment, comparisons of cultural practice or temperature treatments are presented here as main effects from two-way ANOVAs for the two isolate treatments combined (for disease severity and plant growth reduction data) and for the three inoculum treatments combined (for plant weight data).

Effect of different types of wounds on disease development. Initially all individual treatments (i.e., wounding treatment and isolate combinations) were compared by one-way ANOVA (Table 3). Some disease occurred in all treatments in which plants were inoculated. However, disease incidence over $50 \%$, significant levels of disease severity, and significant decreases in plant weight occurred only on plants that were wounded and inoculated. Only isolate F12 caused a significant amount of disease on plants inoculated with an infested scalpel; $92 \%$ of the plants had symptoms. In a two-way ANOVA comparing the five wounding treatments and two isolates, there was a significant difference between isolates for the combined wounding treatments in both disease severity and plant weight (Table 1). Isolate F12 was significantly more virulent than isolate F46; mean disease severity values were 2.35 for isolate F12 and 1.96 for isolate F46, and mean plant weights were $4.35 \mathrm{~g}$ for isolate F12 and $5.30 \mathrm{~g}$ for isolate F46.

When wounding treatments were compared for both isolate treatments combined, there was a strong negative correlation $(r=$ $-0.990, P=0.001)$ between disease severity values and plant weights (i.e., plant weight decreased as disease severity increased). Fusarium root and crown rot developed on plants wounded with an infested scalpel. Compared to plants that were inoculated but not wounded, scalpelinoculated plants had greater disease incidence, 18 of $24(75 \%)$ versus 10 of 30 (33\%); greater disease severity; but similar fresh weight (Table 3). However, disease development (based on disease severity and plant weight data) was greater on plants that were wounded and then dipped in a conidium suspension than on plants that were inoculated with an infested scalpel. Disease development was significantly less on plants with wounded roots compared with plants with wounded roots and crowns (Table 3). Disease incidence was $100 \%$, disease severity was greatest, and plant fresh weight was lowest for the two treatments in which both roots and crowns were wounded (Table 3). However, there was no significant difference between these two treatments, which differed only in the severity of wounds to the crown (i.e., incisions or a small piece removed).
Effect of container mix on disease development. Disease development was affected by the relative amounts of peat and bark in container mixes. There was no significant difference in either disease severity or plant growth reduction between isolates of $F$. hostae, but there was a highly significant effect of container mix on all three disease parameters (Table 1). Incidence of Fusarium root and crown rot was reduced when plants were grown in $100 \%$ peat compared to the other container mixes (Table 2). Disease severity was significantly lower in the two mixes containing peat than in the mix containing only bark and was least in the $100 \%$ peat mix (Fig. 1A). Hosta plants growing in peat mixes also had significantly greater fresh weights than those growing in $100 \%$ bark (Fig. 1B). Noninoculated control plants grew better in the peat/bark mixture than in peat or bark alone (mean plant weights of 8.18 $\mathrm{g}, 7.26 \mathrm{~g}$, and $4.76 \mathrm{~g}$, respectively). Consequently, $F$. hostae caused the greatest reduction in plant growth in the mix containing 50\% peat and 50\% bark (Fig. 1C). Plant growth reduction was least for plants growing in $100 \%$ bark because of the relatively low weight and poor growth of noninoculated hostas in this container mix.

Effect of watering schedule on disease development. Disease development was influenced by both watering schedule and isolates of $F$. hostae (Table 1). In this experiment, the two isolates did not differ significantly in disease severity but dif-

Table 3. Effects of wounding treatments on the development of root and crown rot of Hosta 'Francee' plants that were inoculated with isolates F12 and F46 of Fusarium hostae ${ }^{\mathrm{q}}$

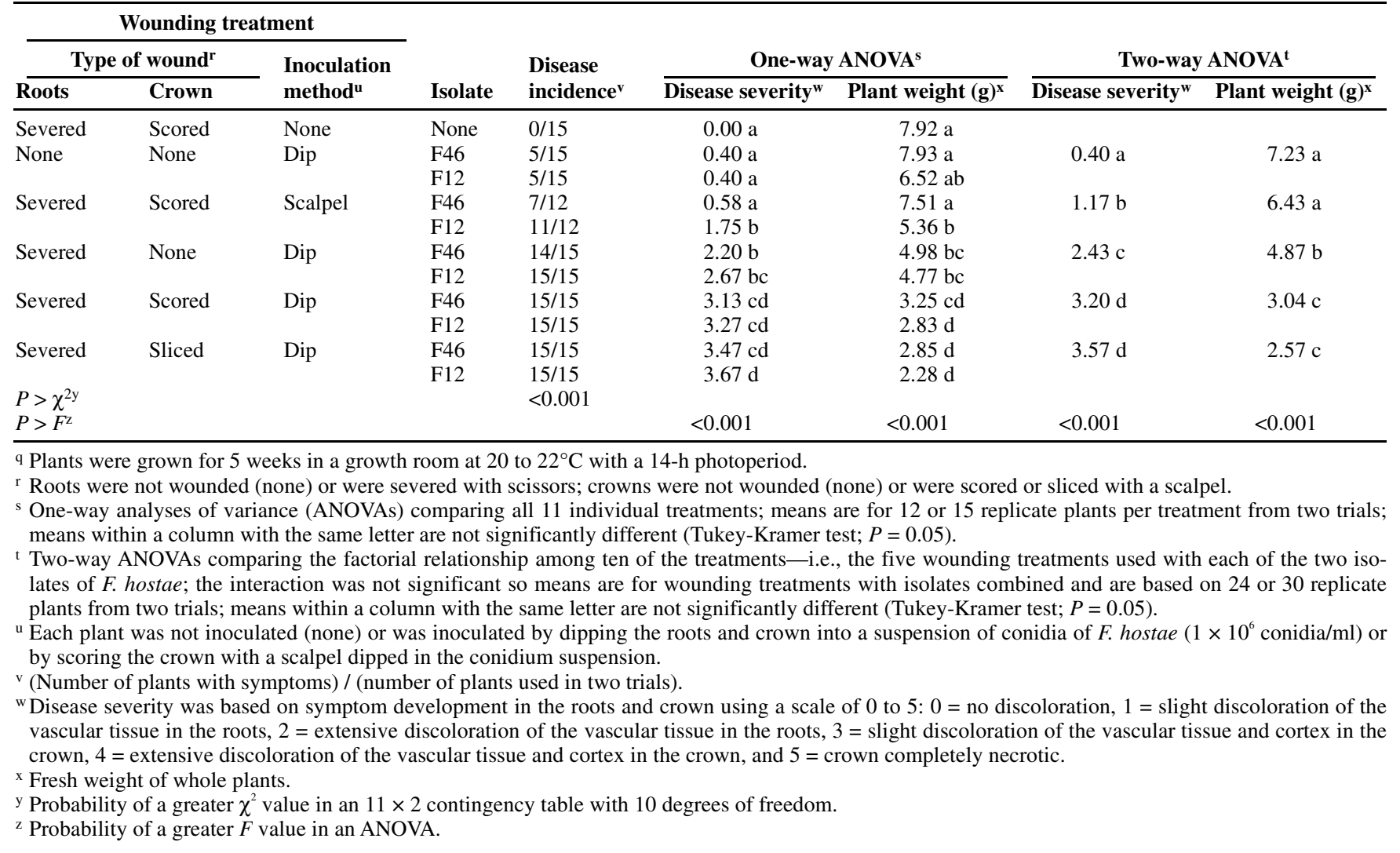


fered significantly in plant growth reduction. Fresh plant weight was affected significantly by inoculum treatment (Table 1). Watering schedule significantly affected both disease incidence (Table 2) and disease severity (Fig. 2A); disease incidence and severity were least on plants growing in container mix kept wet and disease severity was greatest on plants growing in container mix kept dry. There was no significant difference among the three watering treatments in plant weight (Fig. 2B) or plant growth reduction (Fig. 2C).

Effect of temperature on disease development. Development of Fusarium root and crown rot was affected by the temperature at which hosta plants were grown and by isolates of $F$. hostae (Table 1 ). There was a significant difference between isolates in disease severity but not in plant growth reduction. Temperature did not affect disease incidence (Table 2). Disease severity was greater at 18 and $25^{\circ} \mathrm{C}$ than at $32^{\circ} \mathrm{C}$ (Fig. 3A); however, plant growth reduction was greatest at $25^{\circ} \mathrm{C}$ and least at $32^{\circ} \mathrm{C}$ (Fig. 3C). This is because of the significant interaction between inoculum and temperature treatments on plant weight (Table 1). At $25^{\circ} \mathrm{C}$, plant weight was greatest on noninoculated control plants but was relatively low on plants inoculated with isolates F12 and F46 (Fig. 3B). Plant growth reduction was least at $32^{\circ} \mathrm{C}$ because control plants had relatively low weights at this temperature (Fig. 3B).

\section{DISCUSSION}

Development of Fusarium root and crown rot of container-grown hosta plants was affected by type of wounding, container mix content, watering schedule, and temperature. One of the most important outcomes of this study was to confirm that Fusarium root and crown rot developed only on wounded hosta plants. Disease incidence and severity increased and plant weights decreased as the severity of wounds to the roots and crowns increased. We also demonstrated that this disease could result from wounding crowns with an infested scalpel, which has direct implications for the nursery industry. Hostas routinely are propagated in nurseries by dividing crowns into several pieces and using each piece to start a new plant. Therefore, a tool used to divide a diseased crown could transmit inoculum to crowns on healthy plants. Consequently, use of sanitation practices during propagation (e.g., disinfesting tools and work surfaces) should reduce the incidence of Fusarium root and crown rot on hostas in production nurseries. In one nursery in South Carolina, implementation of sanitation practices during propagation reduced the overall incidence of Fusarium root and crown rot (S. N. Jeffers, personal observation).

Our results on the role of wounding in disease development are consistent with those for studies on other diseases caused
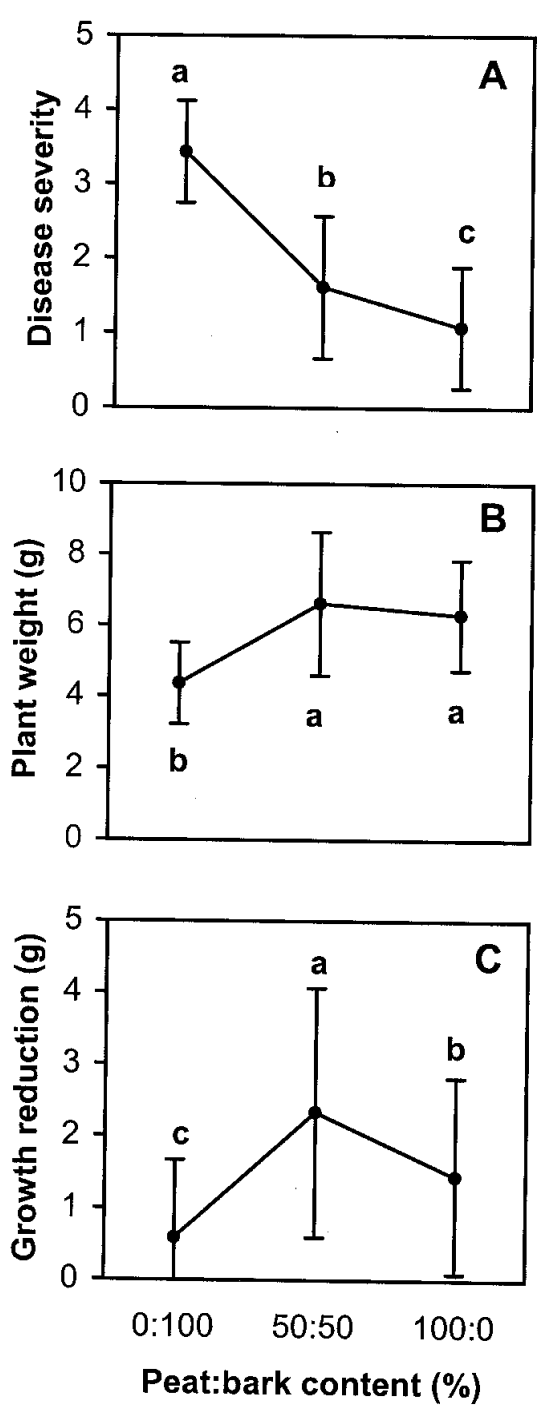

Fig. 1. Effect of container mix content on development of Fusarium root and crown rot on Hosta 'Francee' plants. Roots and crowns of hosta plants were wounded and inoculated with isolate F12 or F46 of Fusarium hostae or not inoculated. Plants were grown for 5 weeks in container mixes composed of different percentages of peat and pine bark; the experiment was conducted twice. Treatments were compared using Fisher's protected least significant difference (LSD; $P=0.05$ ); means with the same letter are not significantly different (error bars = standard deviations). A, Disease severity: based on a scale of 0 to $5(0=$ no discoloration, $1=$ slight discoloration of vascular tissue in roots, $2=$ extensive discoloration of vascular tissue in roots, $3=$ slight discoloration of vascular tissue and cortex in the crown, $4=$ extensive discoloration of vascular tissue and cortex in the crown, and $5=$ crown completely necrotic); values are means for the two isolate treatments combined; LSD $=0.44$. B, Fresh weights of whole plants: values are means for all three inoculum treatments combined; LSD = 0.62 . C, Reduction in plant growth: the difference between fresh weights of control and inoculated plants; values are means for the two isolate treatments combined; $\mathrm{LSD}=0.75$.
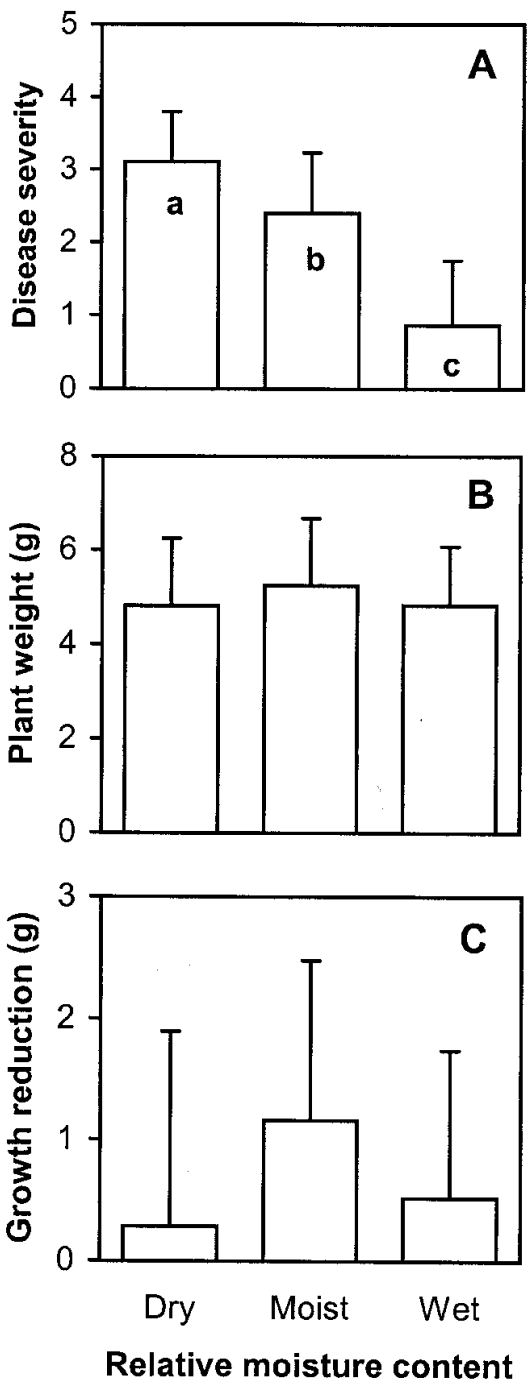

Fig. 2. Effect of watering schedule on development of Fusarium root and crown rot on Hosta 'Francee' plants. Roots and crowns of hosta plants were wounded and inoculated with isolate F12 or F46 of Fusarium hostae or not inoculated. Plants were grown for 5 weeks using three watering schedules that kept the container mix wet, moist, or dry; the experiment was conducted twice. Treatments were compared using Fisher's protected least significant difference (LSD; $P=0.05$ ); means with the same letter are not significantly different (error bars $=$ standard deviations). $\mathbf{A}$, Disease severity: based on a scale of 0 to $5(0=$ no discoloration, 1 = slight discoloration of vascular tissue in roots, 2 = extensive discoloration of vascular tissue in roots, 3 = slight discoloration of vascular tissue and cortex in the crown, $4=$ extensive discoloration of vascular tissue and cortex in the crown, and $5=$ crown completely necrotic); values are means for the two isolate treatments combined; $\mathrm{LSD}=0.42$. B, Fresh weights of whole plants: values are means for all three inoculum treatments combined; means were not significantly different $(P$ $=0.250)$. C, Reduction in plant growth: the difference between fresh weights of control and inoculated plants; values are means for the two isolate treatments combined; means were not significantly different $(P=0.055)$. 

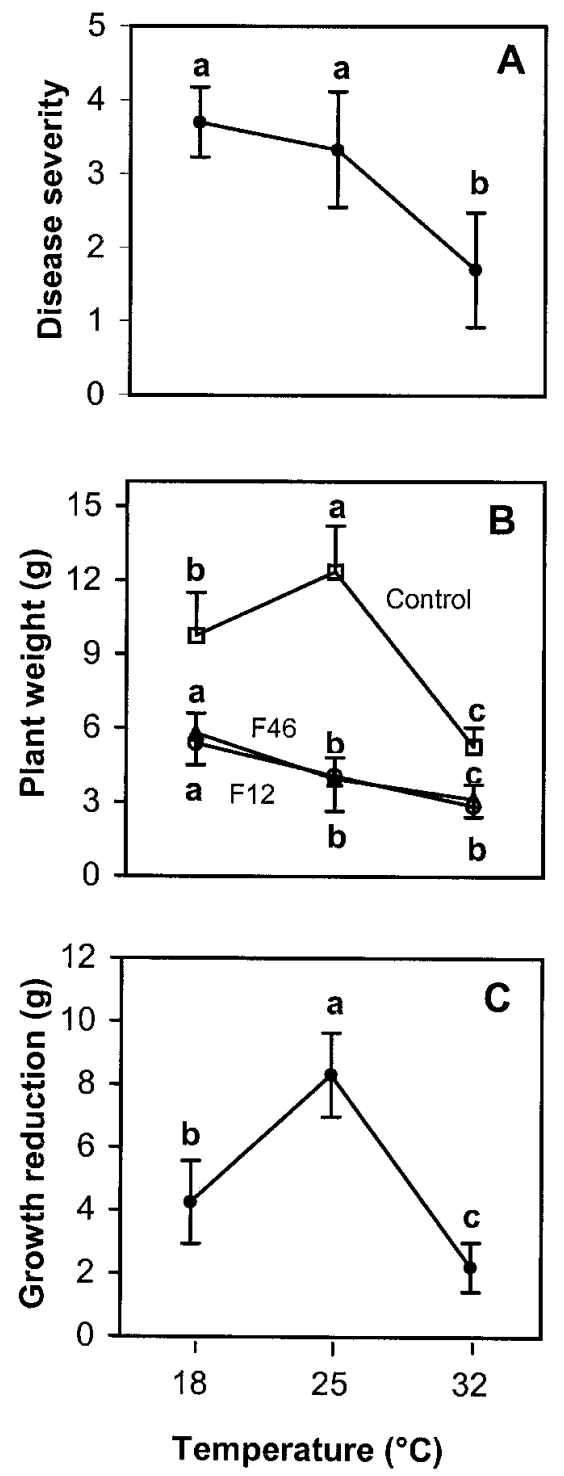

Fig. 3. Effect of temperature on development of Fusarium root and crown rot on Hosta 'Francee' plants. Roots and crowns of hosta plants were wounded and inoculated with isolate F12 or F46 of Fusarium hostae or not inoculated. Plants were grown for 5 weeks in growth rooms at three temperatures; the experiment was conducted twice. Means were compared using Fisher's protected least significant difference (LSD; $P=0.05$ ); means with the same letter are not significantly different (error bars $=$ standard deviations). $\mathbf{A}$, Disease severity: based on a scale of 0 to $5(0=$ no discoloration, 1 = slight discoloration of vascular tissue in roots, $2=$ extensive discoloration of vascular tissue in roots, $3=$ slight discoloration of vascular tissue and cortex in the crown, $4=$ extensive discoloration of vascular tissue and cortex in the crown, and $5=$ crown completely necrotic); values are means for the two isolate treatments combined; $\mathrm{LSD}=0.35$. $\mathbf{B}$, Fresh weights of whole plants: values are means compared at each inoculum level because the temperature $\times$ inoculum interaction was significant; $\mathrm{LSD}=0.73,0.87$, and 1.17 for isolate F12, isolate F46, and the control, respectively. C, Reduction in plant growth: the difference between fresh weights of control and inoculated plants; values are means for the two isolate treatments combined; $\mathrm{LSD}=0.66$. by Fusarium spp. Some species of Fusarium have been reported to colonize or infect host plants only after wounding $(17,22)$. In other situations, the severity of Fusarium root, basal, and crown rots was increased by the occurrence or degree of wounding or by injury from nematodes or insects $(9,15,24,30)$. These species of Fusarium may require certain types of wounds to gain ingress. Wounding destroys physical barriers of plants that normally prevent penetration and also provides sites where pathogens have direct access to susceptible inner plant tissues. In addition, the growth of pathogens may be favored by nutrients leaked into the rhizosphere around wounds, which can directly influence host-pathogen interactions (30). More research is needed to elucidate the role of wounding on infection of hosta roots and crowns by $F$. hostae.

Pine bark (aged, processed, or composted), sphagnum peat, and sand are the predominant components in soilless container mixes used by commercial nurseries in the southeastern United States $(1,14)$. Like most nursery crops, hostas usually are grown in container mixes composed primarily (75 to $100 \%$ ) of pine bark (S. N. Jeffers, personal observation). In this study, development of Fusarium root and crown rot was greatest on hosta plants growing in the container mix composed of $100 \%$ aged and processed pine bark and was significantly less on plants grown in $100 \%$ Canadian sphagnum peat or in a one-to-one mixture of peat and bark. This result concurs with previous findings that container mixes composed of processed, but not composted, bark were conducive to diseases caused by soilborne plant pathogens $(7,28,29)$ and development of root diseases was suppressed by mixes containing slightly decomposed, light-colored sphagnum peat $(5,38)$ - similar to the peat used here.

The Canadian sphagnum peat used in this study was very acidic ( $\mathrm{pH}$ 3.4). High acidity may have contributed to disease suppression since both spore germination and hypha growth by Fusarium spp. can be influenced significantly by $\mathrm{pH}(19,31)$. In addition, the $H$. 'Francee' plants used in this study grew better in mixes containing peat when plants were watered and fertilized regularly. Consequently, reduction in plant growth, which was measured relative to noninoculated control plants, was greater in peat-based mixes. Our results suggest that using peat or a peat-bark container mix for hosta production could reduce disease incidence and severity from Fusarium root and crown rot and also might increase plant growth in the absence of disease.

Watering schedule had less effect on Fusarium root and crown rot of hosta than the other cultural practices examined in this study. Disease severity was greatest on plants growing in dry container mix, and disease incidence and severity were least on plants growing in wet container mix. However, plant growth was not affected significantly by any of the treatments, which suggests that hostas are tolerant of a wide range of soil moisture levels. Our results are consistent with those from studies on other Fusarium diseases $(4,21)$. It appears that some species of Fusarium, like $F$. hostae, are capable of taking advantage of dry soil conditions to gain ingress and cause disease. In the nursery, it would be advantageous to keep hostas well watered, particularly after plants have been divided, to reduce the incidence of Fusarium root and crown rot.

Temperature can be an important factor in the development of diseases caused by Fusarium spp. Previous studies have shown that many Fusarium root diseases are favored by moderate temperatures $(23,26,27,32,39)$. This may be due to the fact that 20 to $25^{\circ} \mathrm{C}$ is optimum for vegetative growth of many species of Fusarium $(10,19,32)$, including $F$. hostae (B. Wang and S. N. Jeffers, unpublished data). In our study, the impact of Fusarium root and crown rot was greatest on hosta plants grown at 18 and $25^{\circ} \mathrm{C}$ and was much less on those grown at $32^{\circ} \mathrm{C}$. Suppression of Fusarium diseases by temperatures over $30^{\circ} \mathrm{C}$ also was reported for other crops, and the detrimental effect of high temperature on pathogen growth might be responsible $(23,32,34)$. In a preliminary study in our laboratory, $F$. hostae was inhibited by high temperature; it did not grow at $35^{\circ} \mathrm{C}$ (B. Wang and S. N. Jeffers, unpublished data).

In the southeastern United States, Fusarium root and crown rot may be suppressed somewhat in July and August when daily temperatures routinely are at or above $32^{\circ} \mathrm{C}$. However, the growing season in this region begins early in the spring and extends late into the fall when moderate temperatures prevail, which are conducive to Fusarium root and crown rot. In addition, it appears that infection of hostas by $F$. hostae primarily occurs when plants are divided and transplanted in nurseries. This process of vegetative propagation is conducted throughout the summer, after plants have fully emerged from the soil. Limiting this activity to mid-summer when daily air temperatures are highest $\left(30\right.$ to $40^{\circ} \mathrm{C}$ ) might minimize infection by $F$. hostae and, therefore, reduce the incidence of root and crown rot in the nursery.

In conclusion, we have demonstrated that the incidence of Fusarium root and crown rot of hosta is closely associated with wounding of the roots and crown and disease development can be influenced significantly by cultural practices and temperature. Therefore, it is possible that production practices could be altered or manipulated to reduce the impact of Fusarium root and crown rot on container-grown hostas in nurseries. Eventually, these cultural practices should become part of an 
integrated disease management program for hosta production.

\section{ACKNOWLEDGMENTS}

We thank H. A. Poole and Fafard, Inc., for providing container mixes; M. Rinck and Agri-Starts III, Inc., for providing hosta plants; and W. C. Bridges, Jr. for providing statistical advice.

\section{LITERATURE CITED}

1. Anonymous. 1997. Best Management Practices Guide for Producing Container-Grown Plants. Southern Nursery Association, Atlanta, GA.

2. Arden, P., ed. 1990. The Hosta Book, 2nd ed. Timber Press, Portland, OR.

3. Baayen, R. P., O'Donnell, K., Breeuwsma, S., Geiser, D. M., and Waalwijk, C. 2001. Molecular relationships of fungi within the Fusarium redolens $-F$. hostae clade. Phytopathology 91:1037-1044.

4. Beddis, L. A., and Burgess, L. W. 1992. The influence of plant water stress on infection and colonization of wheat seedlings by Fusarium graminearum Group 1. Phytopathology 82:78-83.

5. Boehm, M. J., and Hoitink, H. A. J. 1992. Sustenance of microbial activity in potting mixes and its impact on severity of Pythium root rot of poinsettia. Phytopathology 82:259264.

6. Burke, D. W., and Miller, D. E. 1983. Control of Fusarium root rot with resistant beans and cultural management. Plant Dis. 67:13121317.

7. Chen, W., Hoitink, H. A. J., and Madden, L. V. 1988. Microbial activity and biomass in container media for predicting suppressiveness to damping-off caused by Pythium ultimum. Phytopathology 78:1447-1450.

8. Datnoff, L. E., Nemec, S., and Pernezny, K. 1995. Biological control of Fusarium crown and root rot of tomato in Florida using Trichoderma harzianum and Glomus intraradices. Biol. Control 5:427-431.

9. Everts, K. L., Schwartz, H. F., Epsky, N. D., and Capinera, J. L. 1985. Effects of maggots and wounding on occurrence of Fusarium basal rot of onion in Colorado. Plant Dis. 69:878-882.

10. Fravel, D. R., Stosz, S. K., and Larkin, R. P. 1996. Effect of temperature, soil type, and matric potential on proliferation and survival of Fusarium oxysporum f. sp. erythroxyli from Erythroxylum coca. Phytopathology 86:236-240.

11. Geiser, D. M., Juba, J. H., Wang, B., and Jeffers, S. N. 2001. Fusarium hostae sp. nov., a relative of $F$. redolens with a Gibberella teleomorph. Mycologia 93:670-678.

12. Hartman, J. R., and Fletcher, J. T. 1991. Fusa- rium crown and root rot of tomatoes in the UK. Plant Pathol. 40:85-92.

13. Jeffers, S. N., Miller, R. W., and Powell, C. C., Jr. 2001. Fungicides for ornamental crops in the nursery. Pages 409-416 in: Diseases of Woody Ornamentals and Trees in Nurseries. R. K. Jones and D. M. Benson, eds. The American Phytopathological Society, St. Paul, $\mathrm{MN}$.

14. Jones, R. K., and Benson, D. M., eds. 2001. Diseases of Woody Ornamentals and Trees in Nurseries. The American Phytopathological Society, St. Paul, MN.

15. Kalb, D. W., Bergstrom, G. C., and Shields, E. J. 1994. Prevalence, severity, and association of fungal crown and root rots with injury by the clover root curculio in New York alfalfa. Plant Dis. 78:491-495.

16. Mahaffee, W. F. 2001. Biological control of woody ornamental diseases. Pages 435-441 in: Diseases of Woody Ornamentals and Trees in Nurseries. R. K. Jones and D. M. Benson, eds. The American Phytopathological Society, St. Paul, MN

17. Mandeel, Q., and Baker, R. 1991. Mechanisms involved in biological control of Fusarium wilt of cucumber with strains of nonpathogenic Fusarium oxysporum. Phytopathology 81:462-469.

18. Manning, W. J., and Vardaro, P. M. 1977. Soil fumigation and preplant fungicide crown soaks: Effects on plant growth and Fusarium incidence in newly planted asparagus. Plant Dis. Rep. 61:355-357.

19. Marin, S., Sanchis, V., and Magan, N. 1995. Water activity, temperature, and $\mathrm{pH}$ effects on growth of Fusarium moniliforme and Fusarium proliferatum isolates from maize. Can. $\mathrm{J}$. Microbiol. 41:1063-1070

20. McGovern, R. J., Vavrina, C. S., Noling, J. W., Datnoff, L. A., and Yonce, H. D. 1998. Evaluation of application methods of metam sodium for management of Fusarium crown and root rot of tomato in southwest Florida. Plant Dis. 82:919-923.

21. Miller, D. E., and Burke, D. W. 1974. Influence of soil bulk density and water potential on Fusarium root rot of beans. Phytopathology 64:526-529.

22. Mullen, J. M., Hagan, A. K., and Nelson, P. E. 1996. A new stem canker of peanut in Alabama caused by Fusarium oxysporum: A wound-dependent disease. Plant Dis. 80:1301.

23. Nemec, S., and Zablotowicz, R. M. 1981. Effect of soil temperature on root rot of rough lemon caused by Fusarium solani. Mycopathologia 76:185-190.

24. Putnam, A. R., and Lacy, M. L. 1977. Asparagus management with no-tillage. Research Report No. 339. Agric. Exp. Sta., Michigan State University, East Lansing, MI
25. Schmid, W. G. 1991. The Genus HostaGiboshi Zoku. Timber Press, Portland, OR.

26. Siddiqui, W. M., and Halisky, P. M. 1968. Influence of soil temperature on deterioration of red clover roots by Fusarium roseum. (Abstr.) Phytopathology 58:1067.

27. Sippell, D. W., and Hall, R. 1982. Effects of pathogen species, inoculum concentration, temperature, and soil moisture on bean roo rot and plant growth. Can. J. Plant Pathol. 4:1-7.

28. Spencer, S., and Benson, D. M. 1982. Pine bark, hardwood bark compost, and peat amendment effects on development of Phytophthora spp. and lupine root rot. Phytopathology 72:346-351.

29. Stephens, C. T., and Stebbins, T. C. 1985 Control of damping-off pathogens in soilless container media. Plant Dis. 69:494-496.

30. Stutz, J. C., Leath, K. T., and Kendall, W. A. 1985. Wound-related modifications of penetration, development, and root rot by Fusarium roseum in forage legumes. Phytopathology 75:920-924.

31. Thompson, D. P., Metevia, L., and Vessel, T. 1993. Influence of $\mathrm{pH}$ alone and in combination with phenolic antioxidants on growth and germination of mycotoxigenic species of Fusarium and Penicillium. J. Food Prot. 56:134-138.

32. Vakalounakis, D. J. 1996. Root and stem rot of cucumber caused by Fusarium oxysporum f. sp. radicis-cucumerinum f. sp. nov. Plant Dis. 80:313-316.

33. Vilich, V. 1993. Crop rotation with pure stands and mixtures of barley and wheat to control stem and root rot diseases. Crop Prot. 12:373-379.

34. Wang, B., Dale, M. L., and Kochman, J. K. 1999. Studies on a pathogenicity assay for screening cotton germplasms for resistance to Fusarium oxysporum f. sp. vasinfectum in the glasshouse. Aust. J. Exp. Agric. 39:967-974

35. Wang, B., and Jeffers, S. N. 2000. Effects of cultural practices on Fusarium root and crown rot of hosta. (Abstr.). Phytopathology 90:S129.

36. Wang, B., and Jeffers, S. N. 2000. Fusarium root and crown rot: A disease of containergrown hostas. Plant Dis. 84:980-988.

37. Warncke, D. D. 1986. Analyzing greenhouse growth media by the saturation extraction method. Hortic. Sci. 21:223-225.

38. Wolffhechel, H. 1988. Suppressiveness of sphagnum peat to Pythium spp. Acta Hortic. 221:217-222

39. Wong, D. H., Barbetti, M. J., and Sivasithamparam, K. 1984. Effects of soil temperature and moisture on the pathogenicity of fungi associated with root rot of subterranean clover. Aust. J. Agric. Res. 35:675-684. 